\title{
Clio
}

Women, Gender, History

$40 \mid 2014$

Making Gender with Things

\section{A magazine to make you beautiful: Votre Beauté and the cosmetics industry in the 1930s}

Un magazine pour se faire belle: Votre Beauté et l'industrie cosmétique dans les années 1930

\section{Alexie Geers}

Translator. Helen Tomlinson

\section{(e) OpenEdition}

\section{Journals}

Electronic version

URL: http://journals.openedition.org/cliowgh/740

DOI: 10.4000/cliowgh.740

ISSN: 2554-3822

Publisher

Belin

\section{Electronic reference}

Alexie Geers, «A magazine to make you beautiful: Votre Beauté and the cosmetics industry in the 1930s », Clio [Online], 40 | 2014, Online since 15 April 2015, connection on 01 May 2019. URL : http:// journals.openedition.org/cliowgh/740 ; DOI : 10.4000/cliowgh.740 


\section{A magazine to make you beautiful: Votre Beauté and the cosmetics industry in the 1930s}

\section{Alexie GEERS}

Until the 1930s, most women's magazines in France provided wellto-do ladies with the cultural content and codes of elegance required in polite society, thereby adopting the role of etiquette handbooks in periodical form. This era also saw the emergence of a small number of feminist journals advocating women's rights and introducing an educated and literate female readership to the notions of universality and equality of the sexes. ${ }^{1}$

From the 1930s onwards, a new type of women's press emerged in France and developed the theme of beauty. The idea of beauty, which had previously been associated with clothing or nature, was reconfigured by the editorial line of the new periodicals and now defined in terms of body care. The first of these publications, Votre Beauté, was created by Eugène Schueller, the founder of L'Oréal. Initially, it was the supplement to a professional journal for hairdressers ${ }^{2}$ entitled La Coiffure et les modes. Between 1909 and 1931, most articles in the supplement were to do with hairdressing. In 1932, the content of the publication changed and it became a magazine in its own right, available for sale in kiosks under the title Beauté, coiffure, mode, and later Votre Beauté.

The current article considers how this publication formulated a new definition of beauty. Its analysis extends from the magazine's early years (1909-1932), with their focus on hairdressing and fashion, to the emergence of an idea of beauty associated with cosmetics

1 Riot-Sarcey 2011.

2 The professional journal for hairdressers was called La Coiffure de Paris. 
(1932-1935). In a context in which manufacturers and cultural industries were devoting increasing attention to women, what role did the new publishing formula developed by Schueller play in creating mediatized ideals of feminine beauty?

\section{La Coiffure et les modes (1909-1931). A new publishing formula}

The advent of department stores in the second half of the nineteenth century introduced Parisians to a new kind of shopping experience, ${ }^{3}$ one that Zola would describe in his novel about such a store, $A u$ Bonheur des dames [The Ladies' Delight] (1883). "Ladies" is the apposite word here, for the department store was very much designed with women in mind. Clothing, linens, decorations and perfumes were the main wares on offer in these stores, all of which came under the heading household management, then still the purview of women. A few decades later, manufacturers such as William Procter, Helena Rubinstein, Max Factor and Eugène Schueller all played their part in the emergence of a beauty-products market. ${ }^{4}$ Whereas in the past, female body and above all facial care had been based on homemade artisanal recipes, ${ }^{5}$ women now used industrially produced products, sometimes in specially designed public venues such as hairdressers or beauty salons.

In a period in which manufacturers, with the exception of the garment trade, continued to afford little attention to women, these various entrepreneurs drawn from commerce, cosmetics and hairdressing chose to tailor their products to women, drawing on a Western cultural tradition in which women attract men through their appearance. Thanks to a rise in female employment, particularly in the service sector, ${ }^{6}$ an increasing number of these women were now earning an income and therefore represented a market to be captured. To anchor this industrial output in the social customs of the day, the inventors devised new practices - and new social sites in which they

\footnotetext{
3 De Andia 2006.

4 Jones 2010.

5 Peiss 1998.

6 Battagliola 2004.
} 
could be played out - as well as media through which they could be disseminated. The success of department stores, cosmetics and women's magazines shows that women responded favourably to what was presented to them.

Against the thriving backdrop of the burgeoning cosmetic industries, Eugène Schueller was one of those who chose to target women in a niche in which they had not previously been concerned: hairdressing. Until the end of the nineteenth century, professional hairdressing was synonymous with barber's shops, which were mainly for men and tended men's beards and hair. Women's hairdressing, on the other hand, consisted in wig-fitting for middle-class women, and haircuts at home for the rest. ${ }^{7}$ Women dyed their own hair, using homemade products that caused burns and violent allergic reactions to the scalp. Eugène Schueller was a chemistry student at the Sorbonne when a Parisian hairdresser asked his professor to carry out research into hair dyes. As a student, Schueller worked on this project without success, before going on to pursue a career at the Pharmacie Centrale, where he became a laboratory director. He finally developed a "safe and effective" 8 dye formula in his own kitchen in 1907. Two years later he founded La Société française de teintures inoffensives pour cheveux, which was officially renamed L'Oréal in 1939. He now targeted the dyes he had developed at women from all backgrounds, encouraging hairdressers to throw their doors open to these clients who did not have a place to go to have their hair cut. He made hairdressers his ambassadors, by launching a professional hairdressing magazine - La Coiffure de Paris - in 1909 and founding the L'Oréal hair-dyeing school the following year. To keep women clients occupied during their hair cut, he devised a supplement to this magazine entitled La Coiffure et les modes - the future Votre Beauté which he used as a platform for hairdressing news and trends. Given that the only women's magazines at this time, indeed since the beginning of the nineteenth century, were those aimed at well-to-do

7 Jones 2010.

8 Brandon 2011; Jones 2010. 
women, ${ }^{9}$ La Coiffure et les modes represented a new genre of publication.

In the first period, from 1909 to 1931, all the articles in La Coiffure et les modes are concerned with hairdressing, hair care and hair-related fashion (hats, decorative headpieces, etc.), while the advertisements promote hair-care products - dyes, lotions, shampoos - or accessories such as hair nets, combs and hair clips. Through an analysis of specific hair-related topics and the manner in which they are written, it is possible to detect parallels between the publication's promotional and its editorial content.

\section{Co-written narratives}

Grey hair emerges as a major theme between 1923 and 1928. An increase in the number of adverts for hair dyes goes hand in hand with the development, in the articles, of a discourse presenting grey hair as a sign of old age. In September 1923, a L'Oréal advert tells readers:

"First grey hair ... sign of old age": "Nature is often unfair. It brands women who are still young at heart and in soul with that sign of early ageing: grey hair. In everyday working life and in fashionable society, going grey means being sidelined from every job and every party. It says: 'too old already'. You should therefore maintain your hair's youthful colour for as long as you can. L'Oréal offers simple and perfectly safe solutions to brighten up your hair with marvellous shades of colour."

After 1928, adverts promoting dyes to hide grey hair multiply. A L'Oréal advert published in the issue of 15 February 1928 reads:

"Madame, don't be selfish, don't let people say your husband's wife is old", "you look old, you don't mind making yourself look older than you are arm-in-arm with your young husband", "and so you age everyone around you: your children, your relatives..."

This motif occurs more and more frequently in the pages of the publication and the fight against grey hair becomes increasingly pervasive. In the January 1932 issue, an advertising insert for the hair

9 Sylphide, journal des modes, de littérature, de théatres et de musique, owned by Hyppolyte de Villemessant (1839), L'Écho de la mode, owned by the Huon de Penanster family (1879), Pierre Laffite's Femina (1901), and a few others. 
dye Imédia is set opposite an article entitled "No more grey hair", and the issue concludes with a full-page advert on the back cover for a dye to conceal grey hair. Month after month, the same vocabulary is repeated in advertisements and editorial content alike. A close reading of all the issues over the period reveals how this constructs a coherent narrative around grey hair, the spectre of ageing and the woman abandoned by her husband. Coherent but nonetheless fragmented, for the motifs are scattered across different types of content and different issues and surrounded by numerous other themes. This process of constructing media narratives could be adapted to each new topic, from wayy hair (1927 and onwards) to platinum blonde hair (from 1932).

\section{Visual co-writing}

On 10 October 1925, a full-page advert on the inside cover shows a close-up picture of a woman with crimped hair promoting the Eugène perm. A few pages into the magazine, an article illustrated with pictures of curly-haired young women praises "The charm of young hairstyles" [Le charme des coiffures jeunes]. Wavy hair and ringlets feature in most photographs and drawings from this moment on, with a sharp increase in frequency during 1928. The women, with their crimped permed hair cropped rather short, are shown in profile or three-quarter view, forming a visually coherent ensemble (fig. 1). This graphic technique is repeated issue after issue, accompanied and reinforced by a vocabulary and narrative celebrating the modernity of the new trend. The construction of this second example confirms the coherence of the magazine's approach to fashion trends and reveals that the latter was neither simply textual nor narrative-based, but also visual. 


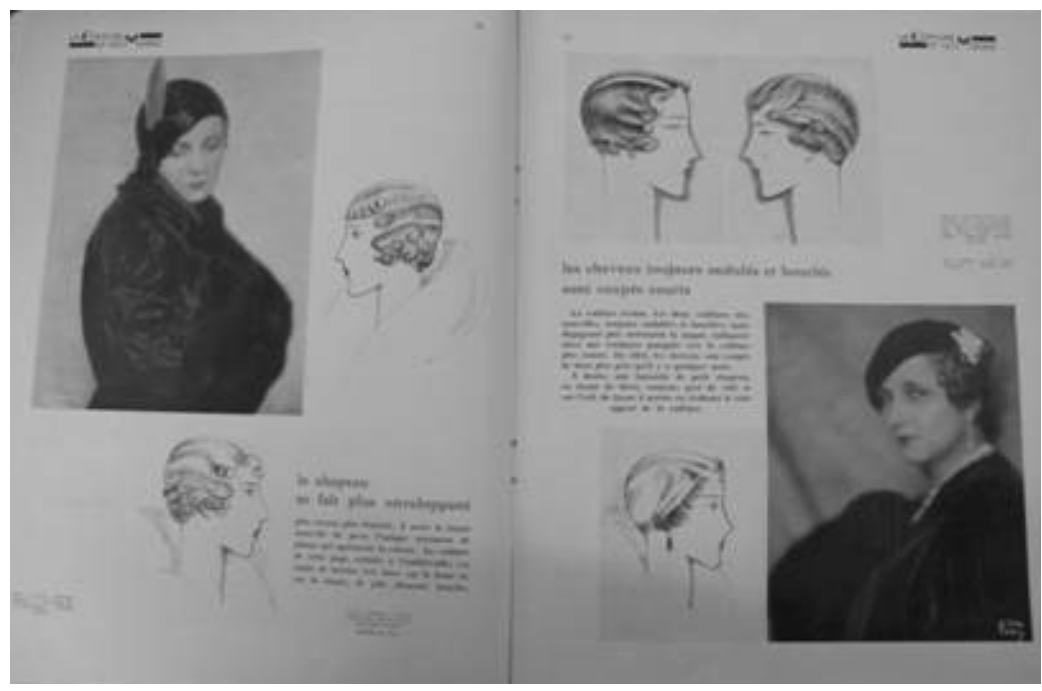

Fig. 1. La Coiffure et les modes, January 1932, no. 263, p. 12-13, private collection.

From the January 1932 issue on, it is the turn of the "platinum blonde" to make its appearance in the supplement. In the article "Our stars on screen" 10 [Nos vedettes à l'écran], hair colour is associated with film stars:

The delightful and urbane "platinum blonde", worn by many a movie star, has proved the most photogenic colour on screen. Indeed, it is to this that Madeleine Renaud of the Comédie Française and Françoise Rosay owe part of their already captivating charm.

The article is illustrated with several photographs of actresses with platinum-blonde hair dressed in elegant evening gowns. The issue ends with an Imédia "blonde platinum" advert on the back cover. A few months later, the back cover of the April 1932 issue carries an advert for L'Oréal Blanc, whose caption reads:

Platinum blonde, the new shade of bleached white hair, is all the rage among movie stars.

10 La Coiffure et les modes, January 1932, p. 16-17. 
The front covers ${ }^{11}$ of the issues from September and October 1932 carry photographs of two platinum-blonde American actresses: Judith Wood (September 1932) and Carole Lombard (October 1932). Page after page and issue after issue, the "platinum blonde" is associated with the movie star: having platinum-blonde hair means having the taste and elegance of a star. According to Edgar Morin (1972), the expression "platinum blonde" originates with the actress Jean Harlow, who starred in Frank Capra's film Platinum Blonde in 1931. This example once again points to the systematized creation of coherent media narratives. If this coherence remains unnoticeable when one flicks through the magazine, that is because its constituent parts are scattered throughout the publication over a period of time. It is revealed only by careful reconstitution.
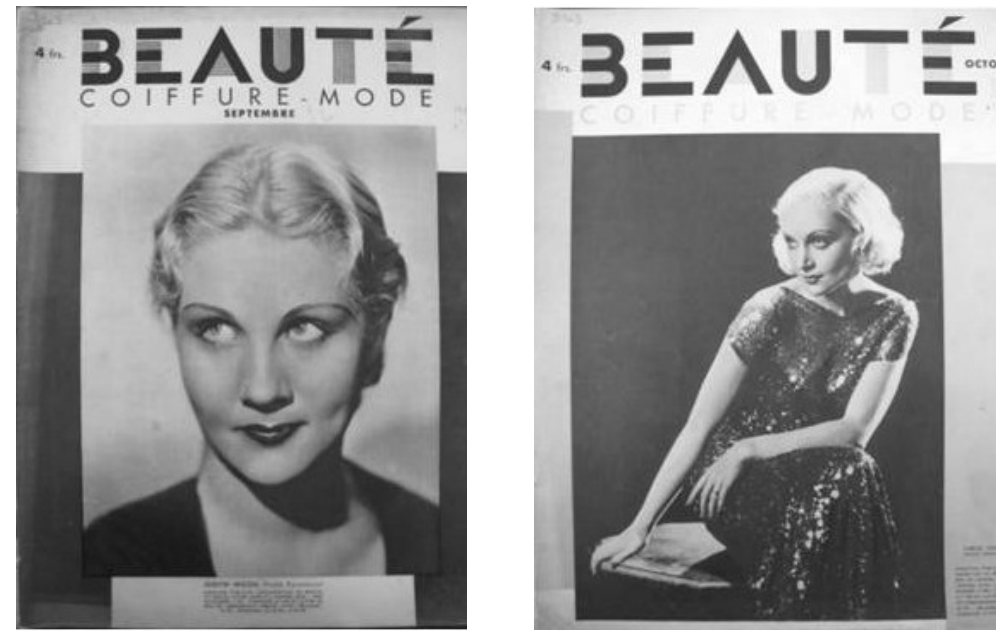

Fig. 2. Covers of Beauté, Coiffure, Mode, September and October 1932, nos 271 and 272, private collection.

11 On the importance of scale in the information hierarchy, see Gunthert 2010a and 2011. 


\section{Breach of contract}

The breach of the journalistic contract - which presupposes the absolute independence of editorial choices and advertising considerations - is not explicit. ${ }^{12}$ Invented by Émile de Girardin in 1836, the press in its modern incarnation was based on the sale of advertising space. ${ }^{13}$ This new source of income halved the price of subscription and led to a concomitant growth in readership. The consequence of this innovation was the coexistence of editorial content and advertisements, the former being presented as the newspaper's raison d'être and the latter as nothing more than a source of income, offsetting the reduced sales price. Though constantly invoked, the separation of the two types of content has been infringed on various occasions throughout the history of the press. This is particularly true of publications belonging to Pierre Lafitte, such as Femina (1901) and Excelsior (1910), in which one can observe a certain spatial proximity between advertising inserts and articles on the same subject. But this propinquity is nothing compared to that developed by Eugène Schueller. La Coiffure et les modes was a new genre of publication in which editorial content and advertising material were systematically co-written.

Schueller played his part in transforming the "traditional" press title into a hybrid package combining the catalogue and the magazine forms. For the manufacturer, the magazine form had an advantage over the catalogue or prospectus, in that it published articles alongside purely promotional material. In journalistic form, Schueller thus provided female readers with complementary information about hair trends and new products. In this system, images are used to promote commercial content and, equally, to convey ideals. This was particularly shrewd, given that the majority of women now frequenting hair salons did not otherwise have access to magazines. Schueller had tapped in to a new audience.

12 Indeed, it is even deliberately concealed: "A clear demarcation must be established between advertisements and the magazine's content (...) A magazine worthy of the name must not let any advertising copy appear within its editorial pages", Votre Beauté, March 1933.

13 Thérenty \& Vaillant 2001. 


\section{Votre Beauté (1932-1935): media narratives of beauty}

In 1928, Schueller extended his manufacturing production to body care by acquiring Monsavon, which he incorporated into the Société des savons français. The cosmetics branch of his company expanded over time, and today is one of the largest multinationals in the sector. The publishing formula Schueller had developed in La Coiffure et les modes was placed at the service of his industrial innovations.

From 1932 onwards, ${ }^{14}$ the supplement was renamed Beauté, coiffure et mode and became a "women's magazine" that could be bought from vendors other than hair salons. ${ }^{15}$ Now widely available for sale, it reached a broader audience of female readers and potential clients. Success was immediate: in December 1933 the title's print run was $92,000^{16}$ copies, compared to 8,950 in April 1932. Study of this transition reveals that the magazine's content had also changed. While between 1909 and early 1931 the magazine had mainly covered hairdressing and fashion, it now introduced - and would later develop - the notion of body-related beauty. The advent of the idea of beauty in the title is initially noticeable because it is pointed out by the editors, who, in the August 1931 issue, announce the creation of a topical column:

A new column will be launched in the forthcoming September issue of $\mathrm{La}$ Coiffure et les modes. Regular advice will be offered to women under the general heading "Beauty. The aim of these articles is to help women keep their figure and youth. With their wealth of detail and wide range of topics, the articles will first discuss which diet to follow to stay supple and svelte, and will then consider the different parts of our bodies we need to protect from the ravages of time. Women across the Atlantic - four fifths of whom are attractive - devotedly observe and practise beauty care, diets and gymnastics. We hope that these articles, which will be based on the experiments and research of well-known practitioners and entirely free of advertisements, will be warmly received by our readers. ${ }^{17}$

14 Denoyelle 1997.

15 Sullerot 1963. The sociologist Evelyne Sullerot pinpoints this year as the date of the magazine's creation, without mentioning its previous incarnation.

16 Table "Increasing print run of Votre Beaute", Denoyelle 1997: 205-206.

17 La Coiffure et les modes, August 1931, p. 27. 
Associated with the body and its embellishment, beauty is presented as a new topic and promoted as such in this announcement to readers. In September 1931, the editors confirm its definition:

Beauty is a harmonious ensemble of forms and proportions that arouses within us feelings of pleasure and admiration [...] Beauty is also a type of perfection specific to a period in time or to a race [...] Beauty is a question of measure and proportion. ${ }^{18}$

This - increasingly important - idea of beauty is eventually namechecked in the title, for in April 1932 La Coiffure et les modes is rechristened Beauté, coiffure, mode. Beauty is presented as an aptitude and a construction rather than as a state. Beauty care is a means to transform this aptitude into reality:

There are no ugly women. There are only women who do not know that they can be beautiful [...] The beauty we wish to talk about here and which we would like all women to achieve is not a perfect proportion of features $[\ldots]$ it is that harmony which every woman can achieve within herself given a little care and attention. ${ }^{19}$

In January 1933, the magazine was permanently renamed Votre Beauté. Analysis of the content of French women's magazines at the end of the nineteenth and early twentieth century confirms that this image of beauty associated with body care did not exist in the press at this time. The subject of "beauty" was covered by a few specialist titles such as Beauté Magazine (1929), Santé, force, beauté (1931) and Le Conseiller de la femme, which associated the notion of beauty with seduction, hygiene and femininity but not yet with body care. The only exceptions in terms of this link between beauty and cosmetics are found in Femina at the very beginning of the century, in Vogue France during the 1920s, and in Harper's Bazaar from 1935 onwards. But these columns are very short inserts ${ }^{20}$ which, judging from their position and the absence of graphics, are not invested with any great importance by the editors. The late 1920s and early 1930s were marked by a media context in which the idea of beauty, though important, had not yet

18 La Coiffure et les modes, September 1931, p. 20-21.

19 Beauté, coiffure, mode, April 1932, p. 14.

20 In Femina, the column was called "Beauty", in Harper's Bazaar, "Cosmetic Urge". 
acquired the significance it would assume in the following decade, in part thanks to Votre Beauté.

The body-care industry was expanding during this period and Schueller was not the only one at work in this domain. In the bodyhygiene sector, William Procter and James Gamble established a soap manufacturing plant in the United States and democratized access to this product. In the beauty-creams sector, Helena Rubinstein, Estée Lauder and Elizabeth Arden spearheaded the use of skincare creams ${ }^{21}$ in women's beauty routines as well as the establishment of beauty parlours. ${ }^{22}$ In the make-up sector, again in the United States, the Polish-born operatic wig-maker and cosmetician Maksymilian Faktorowicz founded Max Factor in 1904. Taking his impetus from the booming Hollywood film industry, he changed the status of make-up which had previously been the preserve of prostitutes ${ }^{23}$-by making it acceptable for all women. In just a few decades, these new skincare practices had remoulded social imaginaries of female bodies.

Votre Beauté occupied an important place in this development of the cosmetics industry and the idea of beauty associated with body care. Several beauty narratives can be detected in the months following the renaming of the magazine. The body is divided into different zones, each requiring special vigilance. The face is also split up into sections that are to be looked after separately. The skin, eyebrows, eyelids, mouth, wrinkles and pores are just some of the areas requiring women's attention.

In the January 1932 issue, the article "Stay slim = stay young" 24 [Restez minces $=$ restez jeunes $]$ and the "Slenderness"25 [Sveltesse $]$ page introduce slimness as a topic in the publication. In Votre Beauté, staying slim means maintaining the figure of a healthy young woman. ${ }^{26}$ The first article is illustrated with a line-drawing of a silhouette with a slender waist and slightly rounded hips, while, on

\footnotetext{
21 Jones 2010.

22 Peiss 1998; Jadzewski 1999; Leveau-Fernandez 2003: 35.

23 Peiss 1998.

24 La Coiffure et les modes, January 1932, p. 20.

25 La Coiffure et les modes, January 1932, p. 22.

26 Stewart 2001.
} 
the following page, two photographs of young women (Wild World studio) bear the caption: "Rhythmic dance is a fashionable sport among young women. It is the school of grace and charm." These pictures of willowy, gracile bodies visually corroborate the text in the articles and captions. According to the magazine, slenderness symbolizes women's self-control and - rather paradoxically, given the numerous interventions needed to become and remain slim - her capacity to be "free". ${ }^{27}$ This idea of control is embodied in visuals showing how to use different types of measuring equipment (figs 3, 4, 5 and 6). The images are coordinated: whatever the technique used - be it photomontage, combinations of photographs and drawings, or photographic mise en scène - each bears out the editorial narrative.
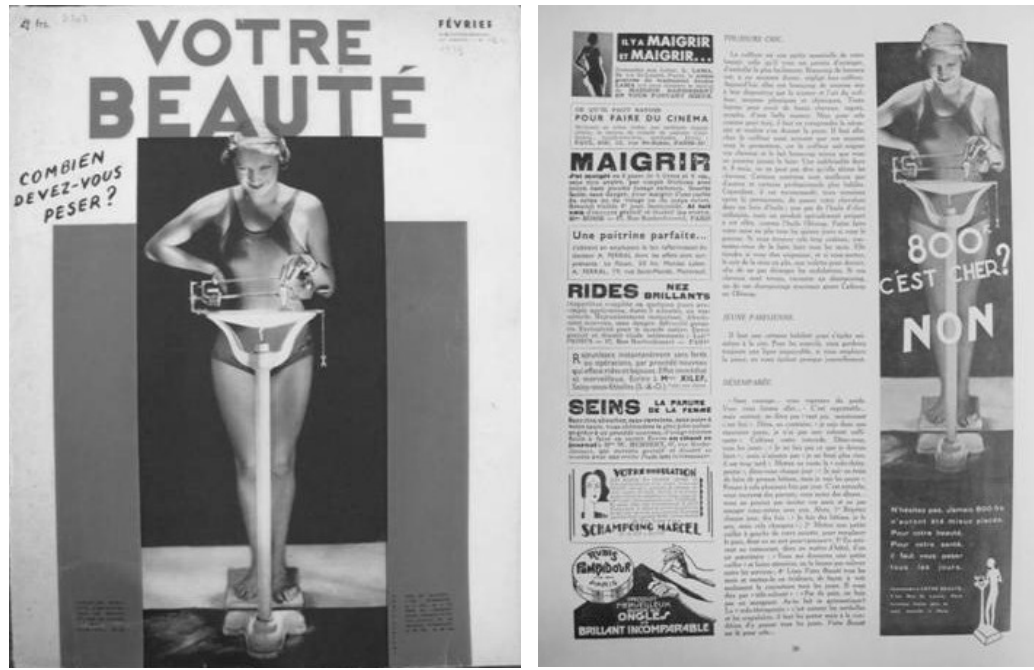

Fig. 3. Cover of Votre Beauté, February 1933, no. 276 and Votre Beauté, May 1933, no. 279 , p. 36 , private collection.

27 Vigarello 2004. 

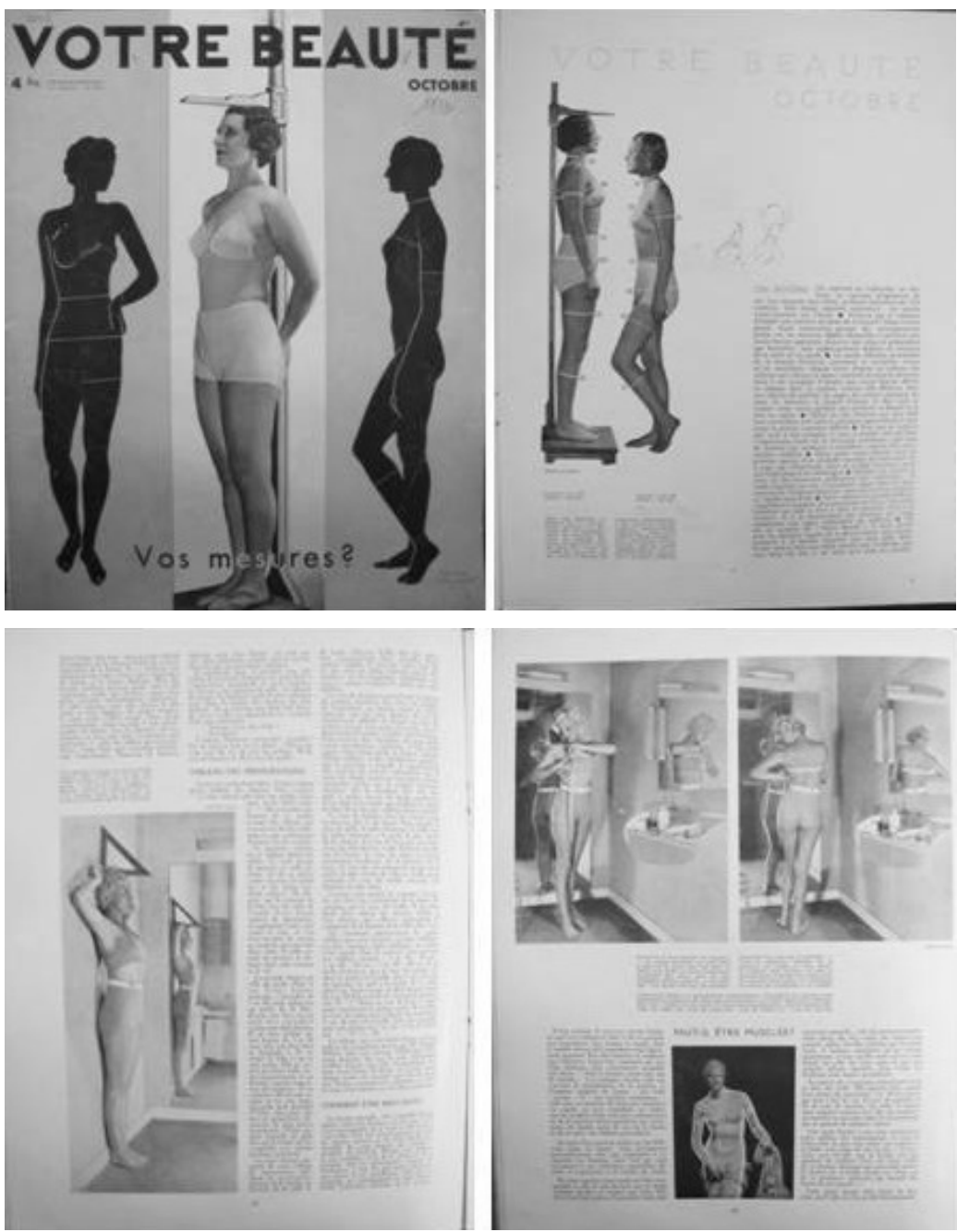

Fig. 4. Votre Beauté, October 1933, no. 284, cover, p. 9, 14 and 16, private collection. 


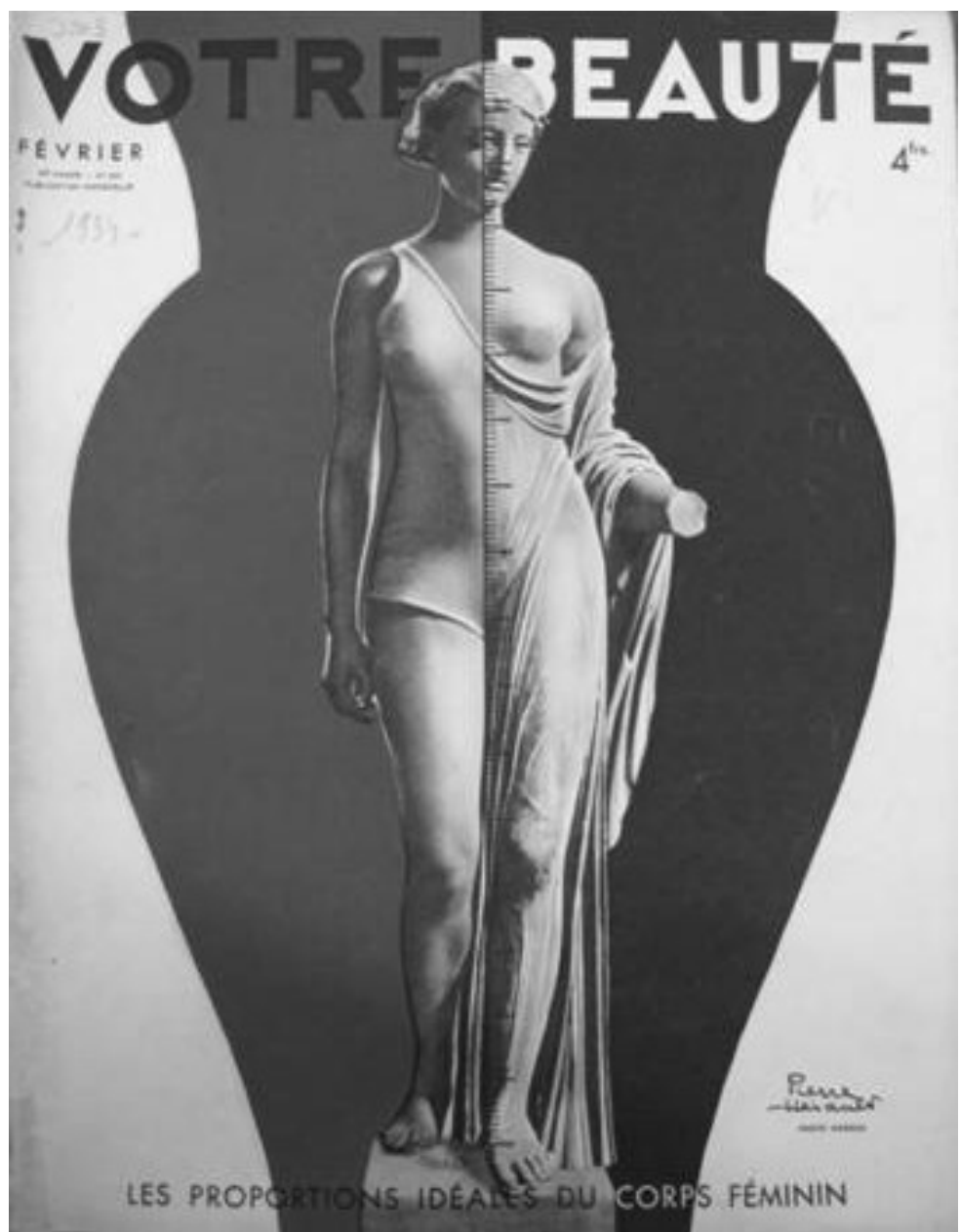

Fig. 5. Cover of Votre Beauté, February 1934, no. 288, private collection. 


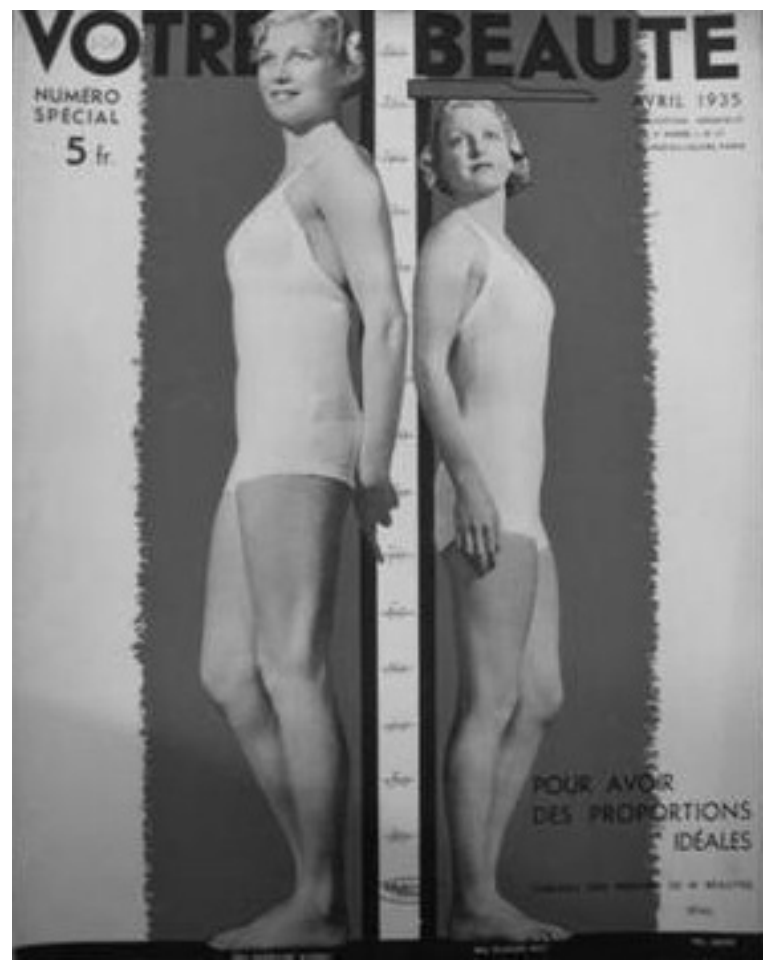

Fig. 6. Cover of Votre Beauté, April 1935, no. 37 (new issue numbering), private collection.

Since the 1920s in particular, slenderness had been associated with a form of freedom. Inspired by the figure of the garconne, ${ }^{28}$ this ideal signalled a desire among women from wealthy backgrounds to break free of the fetters imposed on their bodies. This fashion for slender figures with bobbed hair and loose, flowing clothes did not impose itself permanently ${ }^{29}$ and coexisted with the idea of a meticulously

28 The term "garçonne" derives from Victor Marguerite's novel La Garçonne, published in 1922. It refers to a bob haircut. The garconnes were a near equivalent of the AngloAmerican "flappers", though the French term suggests a certain boyishness in addition to unconventionality in dress and demeanour. [Translator's note]

29 Steele 1988; Zdatny 1994. 
groomed body. Such a body, promoted by the cosmetic industries via the specialist press since the 1930s, had taken on some of the characteristics of Hollywood stars. An alluring body was no longer simply an ideal for actresses, dancers and prostitutes, but one relevant to all women, especially those from the emerging middle class.

This media narrative of slimness was refined over time to include other motifs, such as "slender hips". This new theme emerges in the magazine's content from September 1933 onwards - "Wearing a girdle, but which girdle?” [Porter une ceinture et quelle ceinture?] (fig. 7) in other words at the same time that the magazine begins carrying advertisements for foundation garments. This specific aspect of women's anatomy is subject to a new storyline, a new ideal - "The Hip Problem" 30 - as is attested by the title of the double-page spread in December 1933. Though embedded in the wider quest for slenderness and beauty - "How to slim your hips"31 [Pour maigrir des banches] -, it developed its own narrative and details.

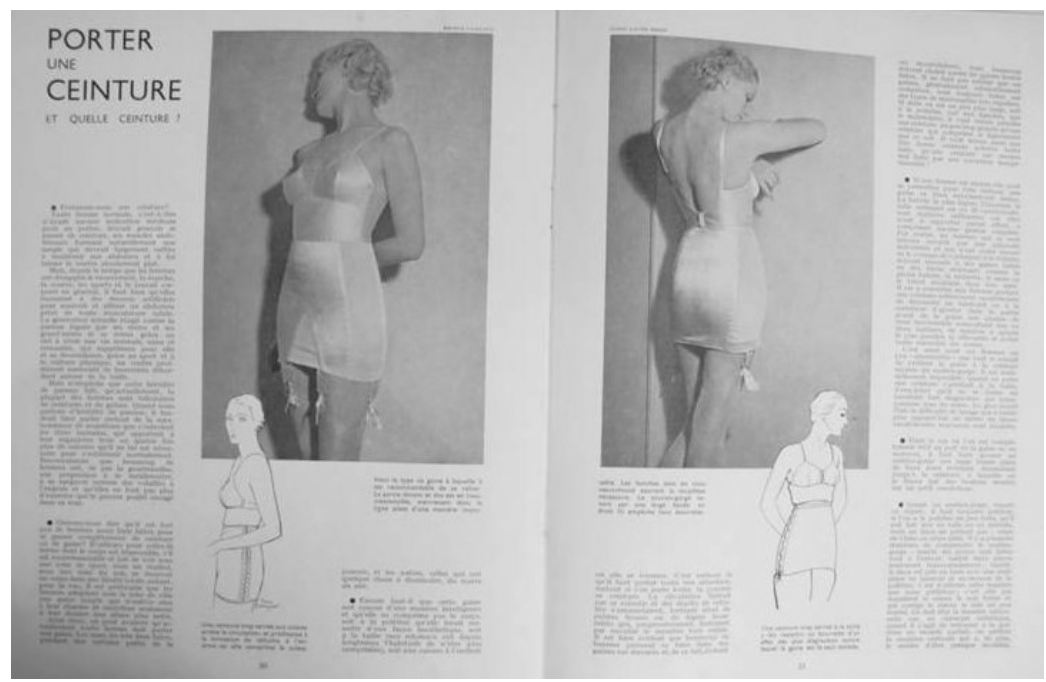

Fig. 7. Votre Beauté, September 1933, no. 283, p. 30 et 31, private collection.

Votre Beauté, December 1933.
$31 \quad$ Votre Beauté, December 1933, p. 22. 
Visually, this narrative is again associated with distinctive images: the women, often photographed with their back turned, all have similar silhouettes, both in the magazine content and the advertisements (fig. 8). This ideal silhouette both effaces all other alternatives and transforms advertising material into journalistic material, or "history into nature". ${ }^{32}$
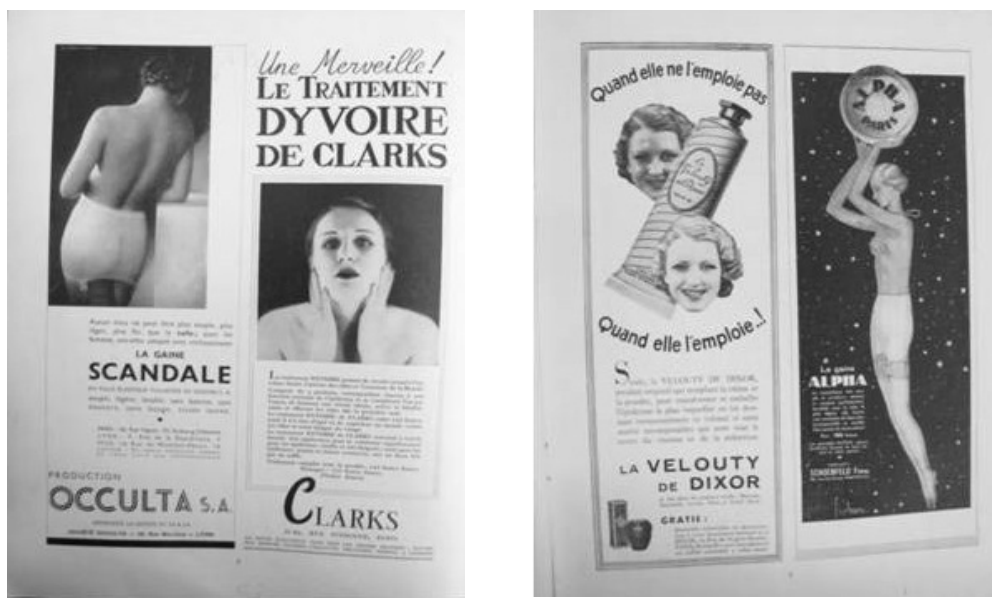

Fig. 8. Votre Beauté, advertisements, February 1934, no. 288, p. 2 and 7, private collection.

As for skin, it must be velvety smooth, fresh and healthy, which involves tackling blackheads, spots and visible pores. This description of ideal skin goes hand in hand with the idea of health and youth. Every problem has a solution: creams, targeted skincare and above all cleansing. "Soap" crops up on every page and advertisements for Monsavon proliferate from 1928 on, the year the company was bought up by Eugène Schueller. The front cover of the March 1935 issue carries a photograph (Joffé) heavily reworked in pencil, showing a woman examining her skin through a magnifying glass. A few hairs and blackheads have been drawn onto the photograph, while the title asks "What can be done about unwanted hair, warts and blackheads?" [Duvets, verrues, points noirs, que faire ?] (fig. 9). On the front cover of the October 1935 issue, a woman carefully washes her face using a small brush (photo: Meerson) (fig. 9).

32 Barthes 1957. 

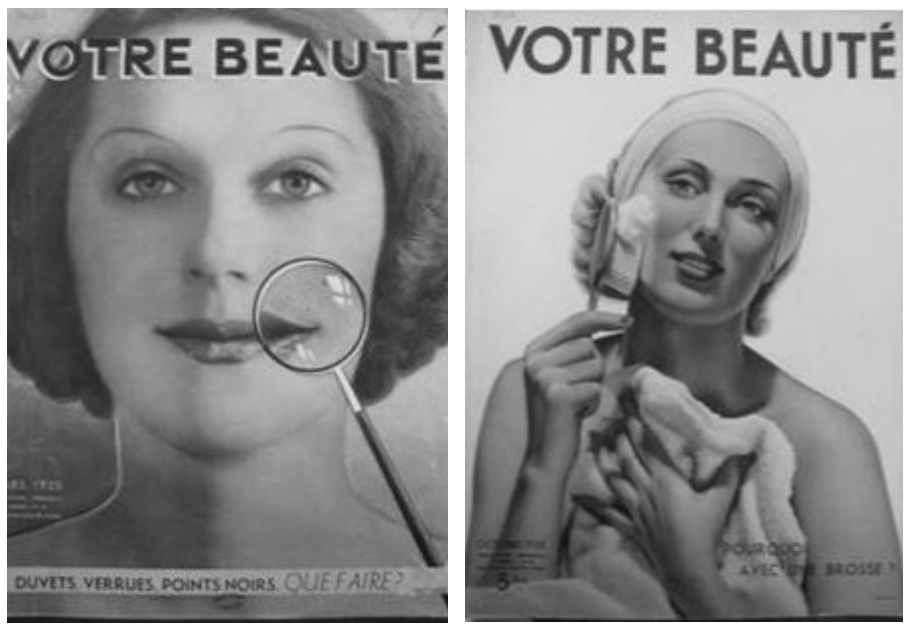

Fig. 9. Votre Beauté, March and October 1935, no. 36 and 43, private collection.

The inclusion of these hygiene and beauty routines on the front cover, coupled with the care taken in producing the images, shows that they were not chosen at random but rather were designed to support and reiterate the narrative, making it more compelling. ${ }^{33}$ In the January 1933 issue, there is a striking visual parallel between the front and back covers. The photograph on the front cover (Scaioni) shows a woman leaning forward to wash, as does the advert (photographer not credited). In both cases, backlighting and touchups give the women's bodies the appearance of silhouettes or statues: the two images are remarkably similar. Blue areas produced by the two-colour printing process used for the cover reinforce this visual homogeneity (fig. 10). This example - together with the front-cover photograph (Scaioni) (Fig. 3) of a woman standing on a pair of scales, which was reused in an advert a few months later - suggests that photographs commissioned by the editors may have paid for themselves by being reused in advertisements. At the very least, it confirms the close relationship that existed between the editors and advertising professionals.

33 Gunthert 2010b. 
These two brief examples, which deserve closer study within their wider cultural context, nevertheless show that female readers were presented with unified "textual-visual" messages. The diffusion of these cohesive narratives - while the neutrality of the magazine's content is all the while constantly reaffirmed - enables them to appear objective through the effacement of all other alternatives. ${ }^{34}$ When repeated issue after issue, this standardization naturalizes ideals ${ }^{35}$ of beauty associated with the use of cosmetics. Photography, which from 1932 on gradually displaces line-drawings in this system, "reinforces the suggestiveness of the technique thanks to the authenticity it confers" 36 and feeds in to the narratives' persuasiveness. On 13 February 1939, the Société d'éditions modernes parisiennes - the publishing house behind Votre Beauté, and again founded by Eugène Schueller - released a new magazine called Votre Bonbeur (Your happiness). Though the quest for beauty is more strongly associated with happiness in this new publication, it reproduces the narrative and visual techniques developed by Votre Beauté.
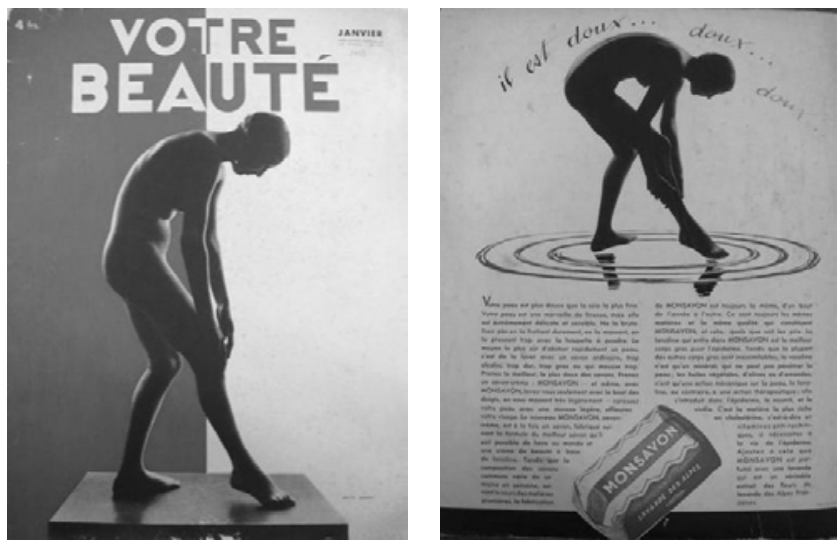

Fig. 10. Votre Beauté, January 1933, no. 275, private collection.

\footnotetext{
34 Rossella Ghigi's detailed study of cellulite (2004) deserves mention here for its exemplary historicization of media narratives.

35 Gunthert 2010c.

36 Gunthert 2010b.
} 
The journalistic form invented by the manufacturer made a lasting impression on women's magazine publishing, since its operating principles, as well as the cosmetics-inflected definition of beauty it developed, set the tone others would follow. The two inventions would shape the form and content both of later women's magazines, such as Marie-Claire (1937) and Elle (1945), and of existing ones, which refined their themes and format from this point on. Votre Beauté transformed the look of the women's periodical, which went from being a guide to good manners for ladies to a beauty magazine for the masses. Among other ideals, Votre Beauté made the the fight against both ageing and over-generous curves into a sine qua non and thereby contributed to diffusing the contemporary imaginaries of feminine beauty developed by the flourishing cosmetics industries.

Translated by Helen TOMLINSON

\section{Bibliography}

Barthes, Roland. 1957. Les Mythologies. Paris: Éditions du Seuil.

Battagliola Françoise. 2004. Histoire du travail des femmes. Paris: La Découverte, coll. "Repères".

BRANDON, Ruth. 2011. La Guerre de la beauté, comment L'Oréal et Helena Rubinstein ont conquis le monde. New-York: HarperCollins.

De Andia Béatrice \& Caroline François (dir.). 2006. Les Cathédrales du commerce parisien. Grands magasins et enseignes. Paris: Action artistique de la Ville de Paris.

Denoyelde Françoise, 1997, Les Lumières de Paris, II, Paris, L'Harmattan.

GunTHERT André, 2010a, L'échelle de l'information, L'atelier des icônes (en ligne: http://culturevisuelle.org/icones/568).

— 2010b, L'illustration, ou comment faire de la photographie un signe. L'Atelier des icônes (en ligne : http://culturevisuelle.org/icones/1147).

- 2010c, La lune est pour demain. In La Performance des images, ed. Alain Dierkens, Gil Bartholeyns \& Thomas Golsenne, 169-178. Bruxelles, Éditions de l'Université de Bruxelles.

— 2011. L'image qui rétrécit, leçon de narratologie visuelle. L'atelier des icônes (en ligne : http://culturevisuelle.org/icones/2233). 
JADZEWSKI, Catherine. 1999. Helena Rubinstein. Paris: Éditions Assouline.

JONES, Geoffrey. 2010. Beauty Imagined, a History of the Global Industry. Oxford: Oxford University Press.

Leveau-Fernandez, Madeleine. 2003. Helena Rubinstein. Paris: Flammarion, coll. «Grandes biographies ».

Morin, Edgar. 1972. Les Stars. Paris: Éditions du Seuil.

PEISS, Kathy. 1998. Hope in a Jar, the Making of America's Beanty Culture. Ontario: Fitzenry and Whiteside Ltd.

Rhossela, Ghigi. 2004. Le corps féminin entre science et culpabilisation. Autour d'une histoire de la cellulite. Travail, genre, société 12: 55-75 (en ligne: http://www.cairn.info/revue-travail-genre-et-societes-2004-2-page-55.htm )

RioT-SARCEY, Michèle. 2011. La presse féministe : la politique des femmes ou la plume exclusive. In La Civilisation du journal, histoire culturelle et littéraire de la presse francaise an XIXe siècle, ed. Dominique Kalifa, Philippe RéGnier, Marie-Eve Thérenty \& Alain VAILLANT, 543-555. Paris: Nouveau Monde Édition.

StEeLe, Valérie. 1988. Paris Fashion: a cultural history. New York: Oxford University Press.

STEWART, Mary Lynn. 2001. For Health and Beauty: physical culture for Frenchwomen, 1880s-1930s. Baltimore: Johns Hopkins University Press.

Sullerot, Evelyne. 1963. La Presse féminine. Paris: Armand Colin.

Thérenty, Marie-Eve, and Alain Vaillant. 2001. 1836. L'An I de l'ère médiatique. Analyse littéraire et historique de La Presse de Girardin. Paris: Nouveaux Mondes Éditions.

Vigarello, Georges. 2004. Histoire de la beauté. Le Corps et l'art d'embellir de la Renaissance à nos jours. Paris: Éditions du Seuil.

ZDATNY, Steven. 1994. La mode à la garçonne, 1900-1925. Le Mowvement social 174: 23-56. 